\title{
Adriaan Reland's Legacy as a Scholar of Islam
}

\author{
Lot Brouwer
}

In 1705 Adriaan Reland published his De religione Mohammedica, ${ }^{1}$ which has been regarded as a turning point in Western attitudes to Islam. ${ }^{2}$ In his preface Reland describes the primary objective of the work as 'enquiring into the Mahometan Religion, and representing it as it really is.. ${ }^{3}$ As Reland argues, the study of other religions in general is often tarnished by misconceptions due to the struggles both between Jews, Muslims and Christians, and between Christian confessions. ${ }^{4}$ Consequently, he continues, the current image of Islam is primarily a Christian invention and does not correspond to reality. Reland had already mentioned the many misconceptions and 'absurdities' that characterised the traditional study of Islam in his inaugural lecture at the University of Utrecht in 1701. As he had then argued, a better, more objective study of the religion was of the utmost importance. ${ }^{5} \mathrm{He}$ writes in his preface to De religione Mohammedica: 'Truth, wherever it is, should be search'd after', and the aim of his publication is therefore to present the Islamic religion 'as it is taught in the Mahometan Temples and schools' ${ }^{6}$

On the one hand recent scholars have praised Reland's approach to Islam. David Pailin's Attitudes to other Religions lists the author as one of the most important scholars responsible for the changing attitude towards Islam in Europe in the seventeenth and eighteenth centuries, and Gerard Wiegers agrees that Reland's publication was the first attempt to provide an authentic image of Islam based on primary sources. ${ }^{7}$ Similarly, Alastair Hamilton describes Adriaan Reland as an 'outstanding Orientalist' who studied Islam 'in

1 My references are to the contemporary English translation: Reland, Of the Mahometan Religion, Two Books, London 1712, p. 8. This, however, is a translation of the first Latin edition of 1705 . When referring to the second Latin edition of 1717 I shall refer to the Latin.

2 See Hamilton, 'From a “closet at Utrecht"', p. 243; Van Leeuwen and Vrolijk, 'Oriëntalistiek in de Lage Landen', p. 86.

3 Reland, Of the Mahometan Religion, London 1712, p. 8.

4 Reland, Of the Mahometan Religion, pp. 5-9. See also Roling, 'Humphrey Prideaux, Eric Fahlenius, Adrian Reland, Jacob Ehrharth und die Ehre des Propheten: Koranpolemik im Barock', p. 71.

5 Hamilton, 'Adrianus Reland (1676-1718)', p. 26.

6 Reland, Of the Mahometan Religion, p. 8.

7 Wiegers, 'De Nederlanden en islam in de zeventiende eeuw'. 


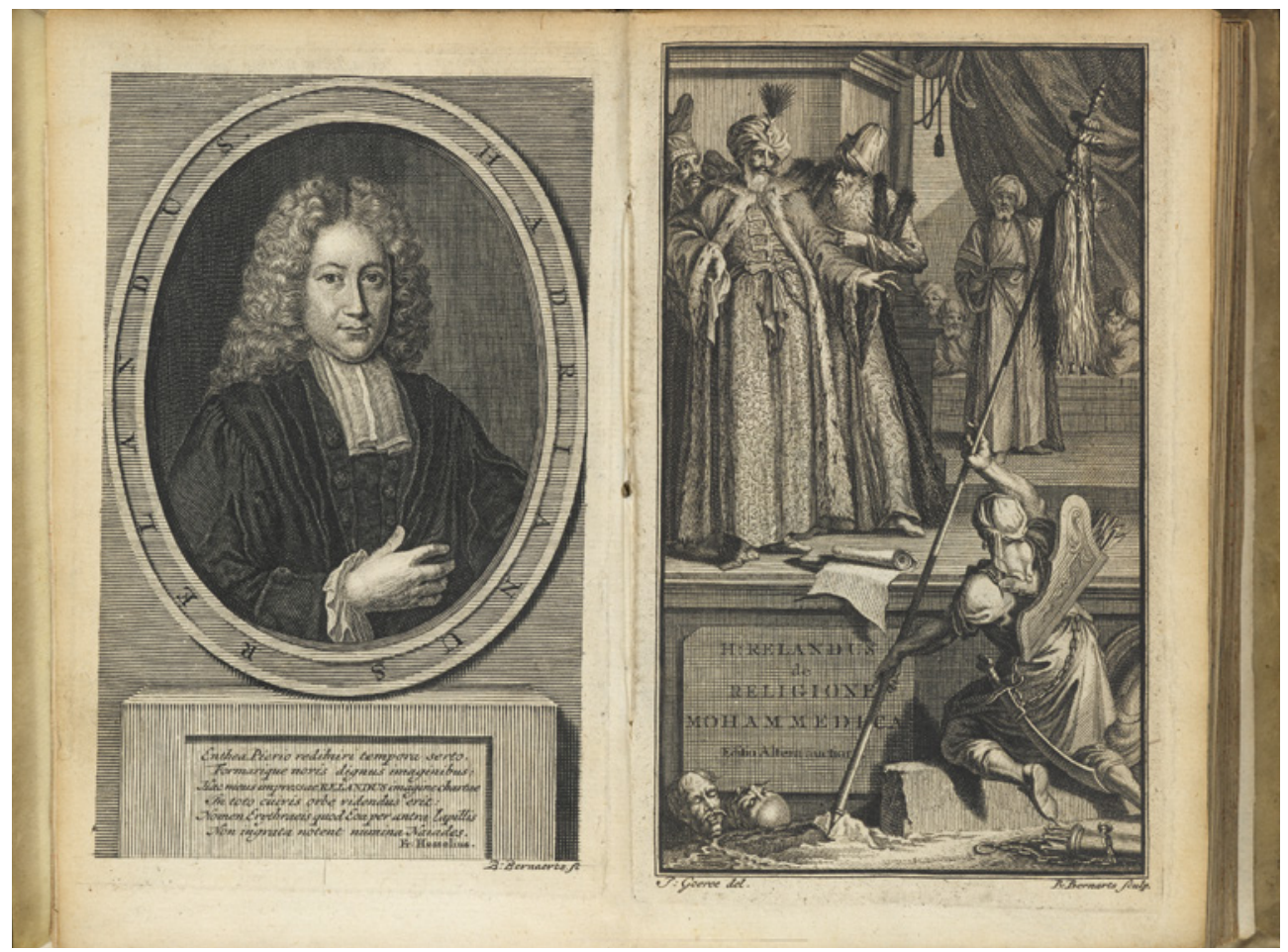

FIGURE 2.1 Adriaan Reland, De religione Mohammedica (1705), frontispiece of the second edition (with a 'Turkish scene'), 1717 .

COURTESY ALLARD PIERSON, UNIVERSITY OF AMSTERDAM, OTM: OK 61-1596

the light of reason.8 ${ }^{8}$ On the other hand De religione Mohammedica has also received attention for its content. It is characterized as an important source of information that contributed significantly to the contemporary European state of knowledge about Islam. In his Islam and the West Norman Daniel describes it as 'the most important of several books that helped to clear away legend and substitute fact, and only fact', ${ }^{9}$ and Christien Dohmen calls it 'the first (Western-European) scholarly account of the Islamic institutions.10 While the author had previously written two dissertations that related to Islam,11

8 Hamilton, 'Adrianus Reland (1676-1718)', p. 28.

9 Daniel, Islam in the West, p. 318.

10 '[De] eerste (West-Europese) wetenschappelijke beschrijving van de islamitische instituties'. Dohmen, In de schaduw van Sheherazade, p. 65.

11 Exercitatio philogogico-theologica De symbolo Mohammedico (non est Deus nisi Unus) adversus quod S.S. Trinitas defeditur (1696), and Exercitatio philologico-theologica De consensus Mohammedaismi et Judaismi (1696). 
this was his first and only publication fully dedicated to the exposition of the religion. ${ }^{12}$

\section{$1 \quad$ Studying Islam 'from Within'}

De religione Mohammedica consists of two main books, preceded by a preface and followed by an Index. The first book is entitled 'A Short System of the Mahometan Theology' and contains a brief theological compendium, or a confession of faith, in both the Arabic original and a Latin translation. This text was probably taken from the first manuscript that Reland listed in his Index, under the Arabic title Kitāb al-Arba'in fì u sūul al-dīn..$^{13}$ As Reland himself also suspected, this text must have been based on a work by al-Ghazālī, which was itself a condensed version of the latter's magnum opus Ihyya 'ulüm al-dīn. ${ }^{14}$ Most of the first book, however, is taken up not by the compendium itself but by extensive footnotes in which Reland explains, or elaborates on, specific terms and/or passages on the basis of additional (primary) sources and publications, including the works of European scholars and Orientalists. In these footnotes he identifies current misunderstandings with regard to these issues, traces their origins, and corrects them on the basis of his own philological and historical knowledge. Such misunderstandings are also the focus of Book Two, which is subtitled 'Treating of several Things falsly charg'd upon the Mahometans' and in which Reland refutes thirty-eight misconceptions that have been falsely attributed to the Islamic faith.

12 As Alexander Bevilacqua argues, De religione Mohammedica proved 'a great success for a little work by a scholar who was not exclusively or even primarily occupied with the study of Arabic or Islam'. Bevilacqua, Republic of Arabic Letters, p. 83.

13 I am very grateful to Christian Lange for indicating this manuscript as the source of Reland's theological compendium, as well as for identifying and tracing the corresponding work by al-Ghazālī. I am also thankful to Bart Jaski for sharing the current whereabouts of the original manuscript used by Reland; see also Appendix 2, A fol 1.

14 This work is known in English as The Forty Principles of Religion. While the original work contains a total of forty principles or topics, Reland's theological compendium only seems to have included a selection of these, concentrating on the belief in, and knowledge of, God and the external practices of faith. It is unclear, however, whether Reland only copied part of the manuscript, or if the manuscript itself was only a partial reproduction of al-Ghazālī's text. Determining this would require the consultation of the original manuscript, which is held at Det Konglige Bibliothek in Copenhagen, Denmark (LIX (no. 18 in quarto) = Cod. Arab. 59). See also Bouyges, Essai de Chronologie des CEvres de al-Ghazali, pp. $5^{\mathrm{o}-5^{1} \text {. }}$ 
In 1717 De religione Mohammedica was published in a second, expanded edition. Its list of sources includes two new manuscripts, and, in Book Two, two additional misconceptions are refuted - forty in all. Moreover, in this edition Reland makes use of, and criticizes, the works of an additional number of European Orientalists, above all Ludovico Marracci's Latin translation of the Qur'ann..$^{15}$ It shows how, for Reland, the study of Islam was an ongoing process in which the availability of new sources and the progressive knowledge of the Arabic language could be used to create a better understanding of the religion.

In his preface Reland laments the fact that those who want to learn about Islam are often referred to the works of Christian scholars, which were written against the background of Christian apologetics and are frequently filled with polemical bias and misconceptions. According to Reland, the religion should instead be studied 'in the light of reason'16 and on the basis of Arabic sources, rather than through the eyes of someone else. ${ }^{17}$ This attitude has often been celebrated as highly 'enlightened', and seems to have characterized Reland's views on science and knowledge in general. ${ }^{18}$ However, the idea that Islam had to be studied 'from within', on the basis of genuine Islamic sources such as the Qur'ān and Qurānic commentaries or tafsìr, had already been expressed since the twelfth century by Christian theologians and scholars who could not necessarily be described as 'enlightened'. It had then led to the collection of the so-called Corpus Toletanum, a compilation of Latin translations of texts about Islam and its history intended to offer more information about Islam in the light of the Spanish Reconquista. The collection contained a large number of important sources, including a Latin translation of the Qurān-made by Robert of Ketton (c. 1110-c. 1160) —and excerpts from Qur'ānic commentaries. ${ }^{19}$

15 It is unclear why Reland had not already included the work in his initial publication in 1705 , considering that it had already been published in 1698. A likely, yet surprising, possibility is that no copy of the work had yet reached Utrecht before 1705. See Hamilton, 'After Marracci', p. 179 .

16 In his preface Reland demonstrates several times how, according to him, the plausibility of a religion should be determined by the extent to which, on the basis of its sources, it conflicts or agrees with the 'light of reason'. See Reland, Of the Mahometan Religion, pp. 9,13 .

17 'If any one of our Youth apply himself to the study of Theology ...' Reland complained about the education of prospective Arabists (Of the Mahometan Religion, p. 12), 'he is not advis'd to learn the Arabick, to hear Mahomet speak in his own Tongue, to get the Eastern Writings, and to see with his own Eyes, not with other Peoples'.

18 In all of his scholarly work Reland placed great emphasis on the study of original and authentic sources related to the subject. See Israel, Enlightenment Contested, pp. 615-616.

19 About the Corpus and Robert of Ketton's Qur'ān translation, see Burman, Reading the Qur'an in Latin Christendom 1140-1560; Elmarsafy, The Enlightenment Qur'an; Burman, 
Often driven by anti-Islamic sentiments as well as by the interdenominational polemics of the Reformation, theologians and scholars over the next few centuries voiced the idea that every religion, including Islam, should be studied fundamentally and understood on its own terms. In 1543 such sentiments led to the first printed edition of the Corpus Toletanum-a project that was initiated by Theodore Bibliander (1509-1564) and supported by the Reformers Martin Luther and Philip Melanchthon, who both wrote a preface to the work. In an introductory 'apology' Bibliander argues that accurate knowledge about Islam would be beneficial to both the defence of Christianity and the conversion of Muslims. And, for a humanist like him, such knowledge had to be extracted from texts. ${ }^{20}$ Bibliander's publication has been regarded as the starting point of a new approach to Islam, in which 'distorted second-hand knowledge' was replaced by more reliable sources about the religion ${ }^{21}$-an approach that also formed the basis of Reland's De religione Mohammedica.

Even among the theologians at the University of Utrecht Reland was not the first to express the idea that Islam should be thoroughly studied according to authentic Arabic texts. More than half a century earlier, the professor Gisbertus Voetius (1589-1676) had already condemned the 'coarse ignorance about Mohammedanism' in the West in his Disputatio de Mohammedanismo (1648). ${ }^{22}$ As Voetius had argued, this ignorance was to blame for the Christian failure to defeat Islam. In order to refute the religion, and-Voetius expressed the hope-to convert Muslims through debate, Christians should approach Islam in a scholarly fashion. To this end, they should collect and publish Arabic manuscripts, and study these 'with knowledge of the philosophy and the languages, especially Arabic.'23 Despite being two generations younger, Reland may have indirectly carried out these instructions by Voetius. ${ }^{24}$

'Tafsìr and Translation' pp. 703-732; Bobzin, Der Koran im Zeitalter der Reformation, pp. $46-55$.

$20 \quad$ Loop, Johann Heinrich Hottinger, p. 26.

21 Ibid., p. 26. Bibliander even replaced several of Robert of Ketton's Qur'ān passages by what he considered more accurate translations. See Bobzin, Der Koran, pp. 171-175.

22 Voetius as quoted in Hamilton, 'From a “Closet at Utrecht”, p. 246. On Voetius' Disputatio de Mohammedanismo, including the original Latin text and a Dutch translation, see Van Amersfoort and Van Asselt, Liever Turks dan Paaps?

23 Voetius as quoted in Hamilton, 'From a "Closet at Utrecht”, p. 246.

24 See Van Amersfoort and Van Asselt, Liever Turks dan Paaps, p. 28. 


\section{The Institutionalization of Arabic Studies and Access to} New Islamic Sources

Adriaan Reland's approach to the study of Islam was thus not new. However, at the start of the eighteenth century he was able to rely on improved linguistic abilities, greater knowledge about Islam, and a larger availability of primary sources. ${ }^{25}$ By the end of the seventeenth century the persisting idea that Islam should be understood on its own terms, and with a sound knowledge of the religion and its sources, had contributed to the revival of the study of Arabic. ${ }^{26}$ Facilitated by the increasing contacts with the Islamic world, which granted greater access to Arabic and Islamic sources, Arabic historical, theological, and scientific texts were collected and translated by European scholars such as Thomas Erpenius (1584-1624) and Jacob Golius (1596-1667) in the Netherlands, and Edward Pococke (1604-1691) in England. These texts were often primarily used for the study of the Arabic language, but their Islamic content also contributed to the improvement of knowledge about the religion and the history of the Islamic world. Previously, Islamic history and culture had been studied mainly on the basis of Byzantine histories, but now these works were superseded by newly available texts by Arab historians. ${ }^{27}$ Moreover, with the advancing knowledge of Arabic, corrections could be made to previous (mis)translations.

Adriaan Reland was well aware of the benefits of Arabic studies for the study of Islam, and his philological approach is clear throughout his De religione Mohammedica. In many instances he attributes the prevalent misconceptions about Islam to the lack of understanding of Arabic by scholars and translators such as Robert of Ketton. Reland was able to benefit from the activities and achievements of Orientalists before him. ${ }^{28}$ Most of the manuscripts included in the bibliography (24 out of 30 ) were part of his own library and were acquired either via Orientalists such as Golius, or via contacts within the Dutch East India Company. ${ }^{29}$ Two other manuscripts were located in the library in Amsterdam, and the remaining four were in the private possession of Reland's friend and tutor Heinrich Sike (1669-1712). In addition to Arabic texts these manuscripts include religious documents in Persian, Malay, and

\footnotetext{
25 Loop, 'Islam and the European Enlightenment', p. 24.

26 Hamilton, 'From a "Closet at Utrecht", p. 247.

27 Ibid.

28 See Hamilton, 'From a "Closet at Utrecht", and Bevilacqua, Republic of Arabic Letters, p. 83.

29 See the Index codicum Orientalium manuscriptorum at the end of De religione Mohammedica, right before the alphabetical index.
} 
Javanese, which Reland used to examine the ways in which certain ambiguous Arabic (Qur'ānic) terms and passages were translated into other 'Islamic' languages. ${ }^{30}$ In addition to these manuscripts Reland's work contains many references - both with regard to the study of Islam and of Arabic - to the works of Orientalists such as Johann Heinrich Hottinger (1620-1667), Edward Pococke, Barthélemy d'Herbelot (1625-1695), Ludovico Marracci (1612-1700), Johannes Leunclavius (1541-1594), Jacob Golius, and others. ${ }^{31}$

In terms of factual information about Islam De religione Mohammedica mainly seems to be a reflection and assessment of the contemporary state of knowledge and information about the religion. The work thus added little to what was already known and available. It suggests that Reland's aim was not necessarily to provide new or exhaustive information. ${ }^{32}$ Rather, it was to demonstrate how the study of Islam could and should benefit from an improved knowledge of the Arabic language. Reland shows this in several ways: first, his translation of the Arabic treatise demonstrates what kind of Arabic sources should be used, and reveals the sort of information that such sources contain. Secondly, the footnotes show how the understanding of such texts could be improved with the help of other Islamic sources, the enhanced knowledge of Arabic, or other information from the scholarly field of Oriental studies. They also show how these sources could contribute to a better understanding of other Islamic texts, for example by documenting the Islamic understanding of the Qur'ān. Thirdly, and perhaps most importantly, De religione Mohammedica reveals how current misunderstandings about Islam could be refuted and corrected with the help of a thorough knowledge of Arabic and Arabic texts. In his footnotes in Book One, and, more explicitly, in Book Two, Reland identifies these misconceptions and misunderstandings, traces their origins, and corrects or refutes them on the basis of his own understanding of the Qurān and

30 In this respect he saw the translations by other (Persian and South East Asian) Muslims as more authoritative than those of European orientalists such as Marracci. This is also emphasized by Bevilacqua, Republic of Arabic Letters, p. 84 .

31 As he writes, he has 'several Systems of the Mahometan Theology' in his possession, of which this particular one is the shortest: 'But when I had got several Systems of the Mahometan Theology, and these of great Authority, and compos'd by very famous Men, of all which this is the shortest, and written in a good order, which I here present thee with; I could not allow myself to deny it to the World'. Reland, Of the Mahometan Religion, pp. $17-18$.

This may also be why Reland's preface, in which he expresses his intentions and his 'Enlightened' approach to the religion of Islam, has received more attention in modern scholarship than his exposition of Islam itself. See, for example, Nat, De studie van de Oostersche talen, pp. 11-21; Van Amersfoort and Van Asselt, Liever Turks dan Paaps? 
other Islamic sources. This shows how the greater knowledge of Arabic could be used to rectify misconceptions that were initially caused by mistranslation and that were then perpetuated, and it demonstrates how the exclusive use of genuine Arabic and Islamic sources would reveal those misconceptions and false beliefs.

\section{From Christian Apology to 'Enlightened' Polemics}

Although the knowledge contained in De religione Mohammedica already seems to have been available to, and known by, contemporary Orientalists and readers, it existed within an even larger pool of misconceptions and misunderstandings about Islam. Despite the availability of new source material and the advances in the field of Oriental studies, seventeenth- and eighteenth-century publications about Islam were often still interlaced with polemical and apologetic stereotypes and Christian misconceptions.

A clear case in point are the writings of Humphrey Prideaux (1648-1724). In his A Letter to the Deists (1696) and The True Nature of Imposture (1697), the Oxford scholar displays an ambiguous attitude towards the study of Islam. On the one hand, he uses the works of contemporary Orientalists to correct old Christian misconceptions about the religion. The stories of Muhammad teaching a bull to bring him the Qur'ān on his horns, and training pigeons to 'converse' with him, for example, are dismissed as 'idle Fables'. ${ }^{33}$ While they have no foundation in truth, Prideaux writes, even great men such as Hugo Grotius $\left(1583^{-1645)}\right.$ and Joseph Scaliger (1540-16o9) have blindly accepted them. ${ }^{34}$ On the other hand, Prideaux still relies heavily on traditional Christian apologetic works, such as Montecroce's Confutatio Alcorani and Bibliander's Machumetis Saracenorum principis, eiusque successorum vitae, ac doctrina, and he uses new knowledge from the field of Oriental studies in order to support old anti-Islamic arguments. ${ }^{35} \mathrm{He}$ insists, for example, on Muhammad's lust for sensual pleasure and worldly power, and presents Muhammad's followers as 'rude and illiterate Barbarians'. ${ }^{36}$ Islam, in turn, is characterized as a deceitful religion that was spread through delusion and aggression, and the Qur'ān is described as a

\footnotetext{
33 Prideaux, The True Nature, p. 5o.

34 Ibid.

35 About 'science as a polemical weapon' ('Wissenschaft als Waffe der Polemik') in the work of Humphrey Prideaux, see Roling, 'Koranpolemik', pp. 62-69.

36 Matar, 'The True Nature'. See Prideaux, The True Nature, p. 41; A Letter to the Deists, p. 40.
} 
storybook full of 'fighting, bloodshed, and conquest'. ${ }^{37}$ Prideaux thus seems both unable and unwilling to part with the Christian apologetic tradition of Islamic studies. Although his name is absent from the list of authors that are opposed by Reland, it has been suggested that Reland was in fact directly responding to Prideaux's The True Nature of Imposture..$^{38}$ Indeed, Prideaux's approach to Islam reflects all that Reland was arguing against in his De religione Mohammedica.

Even scholars who relied exclusively on Arabic sources in their study of Islam, however, could fail to distance themselves from such persistent polemical stereotypes. One of the works that is both used and criticized by Reland in his second Latin edition of 1717 is Marracci's Alcorani textus universus. Driven by the idea that, in order to effectively refute the Islamic religion, one had to know it —or the idea that 'polemic required philology'39— the Catholic priest Ludovico Marracci published what is now considered the first scholarly European translation of the Qur'ann in 1698. Despite the quality of the translation itself, which is acknowledged by Reland as 'the best translation of the Qur'ann that has been published until this day, ${ }^{40}$ the text was accompanied by polemical and apologetic annotations containing old anti-Islamic arguments, thus attesting their persistence. These arguments had no scriptural basis, and therefore, according to Reland, no place in a work about the religion of Islam. As he argues, such arguments 'do not fight with the Mahometan religion, but with their [these Christian writers'] own shadows.' ${ }^{41}$ In this context, Reland's aim seems to have been not only to demonstrate with the help of his 'Labour'42 how Islam should be studied, but also how this study should break down these old stereotypes and misconceptions by relying on authentic Islamic material and by (re)assessing secondary works on the basis of an improved philological understanding of these sources. ${ }^{43}$

37 Matar, 'The True Nature'; Roling, 'Koranpolemik', pp. 62-69.

38 Roling, 'Koranpolemik', p. 72.

39 Bevilacqua, 'The Qur'an translations of Marracci and Sale', p. 95.

40 Reland, De religione Mohammedica libri duo, Utrecht 1717 , sig. ${ }^{* * * * *} 3$ r. For Marracci's prominence in the second edition of De religione Mohammedica, see Hamilton, 'After Marracci', pp. 179-180.

41 Reland, Of the Mahometan Religion, p. 15.

42 On several occasions, Reland describes his own work as an exercise. See Reland, of the Mahometan Religion, pp. 8, 18.

43 Such a 'reassessment' of secondary works can also be found in a Dutch account of the life of Ḥayy ibn Yaqzān (written 'Hai Ebn Jokdan'), in which a Dutch translation of Pococke's Latin translation of the Arabic text by Ibn Tufayl ('Abu Jaaphar Ebn Tophail') is 'newly compared with the Arabic source text, and is enriched with notes about several curious places and sayings' by Adriaan Reland. The author's name is absent from the work, but 
Reland's mission to refute longstanding misconceptions about Islam seems to have been (partly) motivated by his Cartesian view of the nature of the religion. ${ }^{44}$ According to the author one of the gravest misconceptions was the idea that Muslims were irrational and that Islam was an 'unreasonable' superstition..$^{45}$ This view, too, had its roots in Christian apologetics, and it had led to many of the prevailing misconceptions and misinterpretations, such as the idea that Muslims believed in a material God and that they believed they could literally wash away their sins. ${ }^{46}$ Reland, however, writes that 'sense and reason are equally distributed among Men'47 and Muslims should thus be seen as a rational people. ${ }^{48}$ The success of Islam, he argues, can only be explained by the fact that 'that religion, which hath largely spread itself over Asia, Africa, and even Europe, commends it self to Men by a great Appearance of Truth, which is ready to allure them; nor is it so foolish as many Christias esteem it'.49

That Reland viewed Islam as a 'rational' religion did not, however, mean that he saw it as 'true'. Similarly, the author's objective approach did not free his work of polemics. Throughout the publication Reland expresses the longstanding idea that Islam could — and should — be refuted on the basis of a proper, 'Islamic' understanding of the religion. ${ }^{50}$ In this respect, Reland's focus on misconceptions about Islam was not only meant to correct the current image, but also to demonstrate that anti-Islamic arguments based on such misconceptions were futile. With regard to prevailing misconceptions that do not have any foundation in Islamic writings or practices but rather in Christian perception and bias, Reland argues that Muslims will simply not feel addressed, as they do not recognize their own religion in these arguments. Moreover, he

the Biographisch woordenboek der Nederlanden lists it as one of Reland's publications. See De natuurlyke wysgeer.

44 Hamilton, 'After Marracci', p. 179.

45 In stating this, Reland is said to have clearly responded to Ludovico Marracci, who stated in his Qurān translation that the triumph of Islam could be explained by the fact that the world was populated by fools. See Hamilton, 'From a "Closet at Utrecht"', p. 247.

46 Saviello, Imaginationen, p. 158.

47 Reland, Of the Mahometan Religion, p. 13.

48 It is a direct reference to Descartes' Discourse on the Method and the Meditations, Part One, in which Descartes writes that 'Good sense is, of all things among men, equally distributed ...' The Cartesian influence in Reland's work is also recognized by Alastair Hamilton and Ziad Elmarsafy. See Hamilton, 'Adrianus Reland (1676-1718)', p. 25, and Elmarsafy, The Enlightenment Qur'an, p. 14.

49 Reland, Of the Mahometan Religion, p. 13.

50 Loop, 'Islam and the European Enlightenment'. 
demonstrates how such misconceptions are often historically incorrect and caused by insufficient understanding of the Arabic sources. ${ }^{51}$

In other instances Reland takes on the role of devil's advocate in order to show how a Muslim would be able to rebut certain traditional misconceptions. In doing so he often appeals to reason and logic, as well as to his historical and linguistic knowledge. ${ }^{2}$ With regard to the old accusation that the Qurān identifies the Holy Virgin Mary with the sister of Moses, for example, Reland argues that, while the Qurān calls Mary 'the sister of Aaron', it is never specified that this Aaron is the brother of Moses. It could therefore easily be argued that this Aaron was another Aaron, especially since names are not unique. ${ }^{53}$ Even if Muhammad himself was ignorant enough to believe that the Holy Virgin could historically be the sister of Moses and Aaron, Reland continues, it would be highly unlikely that all his followers and the Qur'ān commentators would accept this irrational belief. ${ }^{54}$ With regard to the claim that the Qur'ann wrongfully locates Mecca in Ammon - traditionally used to point out the conflicting and deceptive nature of the Qurān-Reland asks the reader if Muhammad would really have been 'such a Fool' as not to have known the whereabouts of his own place of birth and fatherland. Instead, he writes, this idea is based on a Christian mistranslation. ${ }^{55}$

Even when Reland seems to appreciate the religion or culture of Islam, this usually serves a polemical purpose. When he discusses the religious tolerance of Muslims, for example, this is contrasted with the religious persecutions by Christian rulers. Similarly, Reland praises the fact that Muslims value one another for their skills and talents, rather than for their family status and noble birth. Such usage of Islam in confessional polemics and cultural criticism had a long history, and the very same arguments had already been expressed by authors such as Salomon Schweigger $\left(155^{1-1622}\right) .{ }^{56}$ While Reland thus expressly aimed to detach the study of Islam from centuries of Christian bias and stereotypes, which in itself may have formed a positive step towards the

\footnotetext{
$5^{1} \quad$ See also Bevilacqua, Republic of Arabic Letters, p. 85.

$5^{2}$ Reland's appeal to 'human reason' ('gesunden Menschenverstand') is also pointed out by Roling, 'Koranpolemik', p. 72, as well as Hamilton, 'Adrianus Reland (1676-1718)'.

53 In arguing this, Reland writes in his preface, he speaks 'according to the mind of the Mahometans', rather than his own opinion or interpretation. Reland, Of the Mahometan Religion, p. 18.

54 Reland, Of the Mahometan Religion, pp. 79-81.

55 Ibid., p. 9 o.

56 In his Reyßßeschreibung of 1608 , Schweigger writes that Ottoman nobility stems not from birth, but from virtue. Schweigger, Reyßbeschreibung, p. 16o. See also Bohnstedt, 'The Infidel Scourge of God', p. 20; Geier, 'Zur Rhetorik', p. 20.
} 
emancipation of the field of Islamic studies, De religione Mohammedica was still firmly rooted in traditional anti-Islamic, as well as confessional, polemics. ${ }^{57}$ Ultimately, the work calls for the refutation of Islam with rational arguments founded upon a proper understanding of the religion and its texts-something that was facilitated by contemporary linguistic abilities, specialised knowledge of Islam, and the wider availability of primary sources. ${ }^{58}$ What these arguments should be, however, is never made explicit.

\section{$4 \quad$ New Editions and Translations}

The significance of Reland's De religione Mohammedica was quickly recognized by other scholars such as Edward Gibbon (1737-1794), ${ }^{59}$ George Sale (16971736), ${ }^{60}$ and Jean-Frédéric Bernard (168o-1744), ${ }^{61}$ who used it as an important source in their own writings. Not only did they use it to inform themselves about the religion of Islam, but they also echoed Reland's argument that Islam and its history deserved to be studied objectively both in the light of Christian theology and history, and for its own sake-as the religion and history of a great society. ${ }^{62}$ Reland's refutation of the misconceptions about Islam, on the other hand, directly inspired scholars such as Jacob Ehrharth, who went still further in his defence of Islam and the Prophet Muhammad, whom he even

57 Alastair Hamilton agrees that Reland's arguments for the study of Arabic, including the refutation of Islam, 'show little sign of progressing beyond the standard apologies which had been appearing since the Renaissance'. What was new, Hamilton claims, was Reland's determination to do so on the basis of an objective examination of Islamic sources, which would also refute the longstanding myths about Islam. See Hamilton, 'Adrianus Reland (1676-1718)', p. 3 o.

$5^{8}$ See also Loop, 'Islam and the European Enlightenment'.

59 Gibbon praises Reland and his works in his Decline and Fall of the Roman Empire vol. 3 [1781]. See Hamilton, 'From a "Closet at Utrecht", pp. 244 and 250, and 'Adrianus Reland (1676-1718)', p. 3 .

6o Sale's Qurān translation contains many references to Reland's De religione Mohammedica in the footnotes, especially with regard to debates about the proper translation of Qur'ānic terms. See Sale, The Koran, and Bevilacqua, 'The Qur'an Translations of Marracci and Sale', p. 122.

61 In his Ceremonies et coutumes religieuses de tous les peuples du monde, which appeared in a series from 1723 to 1743 with engravings by Bernard Picart (1673-1733), Bernard drew extensively on Reland's treatise, both in the original Latin and in its French translation of 1721. See Hunt, Jacob and Mijnhardt, The Book that Changed Europe, pp. 261-264.

Ibid. and Hamilton, 'Western Attitudes to Islam', p. 82. 
called 'gifted'. ${ }^{63}$ At the other end of the spectrum churchmen such as Joseph White (1745-1814) used Reland's treatise for the very opposite reason-in order to combat the 'Deist' sympathy for Islam that was expressed by individuals like Ehrharth. ${ }^{64}$ The value of Reland's work was also recognized outside the field of Oriental and Islamic studies and theology. The Enlightenment historian Pietro Giannone (1676-1748) congratulated Reland on his much-needed research, which, indeed, called for the emancipation of the study of Islam and culture. ${ }^{65}$ The German Enlightenment philosopher Christian Wolff, in turn, praised Reland as an important figure of his time, and as the scholar who had, up until then, contributed most to a more tolerant image of Islam. ${ }^{66}$

It is nevertheless hard to determine the direct influence that Reland's $D e$ religione Mohammedica had on the study of Islam. While the author may have been happy to contribute to a genuine representation of Islam in works such as that of Picart and Bernard, he ultimately meant his work to form an example and inspiration, rather than a new and authoritative source for the study of Islam which, as Reland argued, should be examined on the basis of its own sources. Even when works about Islam published after De religione Mohammedica first appeared show substantial similarities, a direct influence cannot be irrefutably established unless made explicit by the author. As we saw, other scholars before Reland already expressed similar approaches, methods, and concerns, and, indeed, Reland himself also built upon the heritage and efforts of such scholars. It is thus hard to put the author and his De religione Mohammedica at the start of a movement or tradition. Rather, Reland and his work seem to have been a prominent reflection of a movement towards the more objective and authentic study and representation of Islam that had started earlier and still continued after the first publication of De religione Mohammedica in $1705 .{ }^{67}$

Regardless of its direct influence, the contemporary success of De religione Mohammedica is reflected by its new editions and translations: In 1717, a second expanded Latin edition was published, and the work appeared in translation

63 'Mohammed war kein Epileptiker, wie die Apologeten behauptet hatten, er war Enthusiast, ja er war begnadet', Roling, 'Koranpolemik', p. 74.

64 Hamilton, 'From a "Closet at Utrecht", p. 25 o.

65 Israel, Enlightenment Contested, p. 615 .

66 Ibid., p. 615 .

67 Indeed, Jonathan Israel refers to Adriaan Reland as 'prominent amongst a number of scholars during this period who made respectable adjustments to the West's image of the Muslim religion', thus attesting the fact that, while he was an important proponent of this movement, he was by no means the only one. See Israel, Enlightenment Contested, p. 615 . 
in English, German, Dutch, and French, thus demonstrating its wide influence even beyond the academic field. ${ }^{68}$ Although Reland's work originally seems to have been above all a scholarly plea advocating a more objective approach toward the subject, the emphasis changed slightly as the work was presented to a wider audience. In its English translation, De religione Mohammedica was best known as part of a collection of texts about Islam entitled Four Treatises Concerning the Doctrine, Discipline and Worship of the Mahometans, which contains Book One and Book Two of Reland's De religione (as two of the four treatises), a text about Turkish liturgy, pilgrimage, circumcision, and care for the sick by the Polish author Bobovius, and a treatise written by the French Orientalist and historian Mathurin Veyssière de Lacroze, discussing and comparing Islam and Socinianism. These texts, of course, have their very own history, but within the English collection they were presented first and foremost, along with Reland's work, as sources of authentic information about Islam. ${ }^{69}$

A similar collection of works, but without a publication date or place, can be found in the British Library under the title Tracts on Mohammedism 1697-1717. It contains the English translation of Adriaan Reland's work and the treatises of Bobovius and Mathurin Veyssière de Lacroze, as well as Humphrey Prideaux's The Life of Mahomet and a short text by Simon Ockley entitled Sentences of Ali, which, the title-page states, was translated from 'Authentick Arabic Manuscripts in the Bodleian Library'. In this collection, again, Reland's work was incorporated as a source of authentic information about Islam and was incorporated into a new English 'canon' of European texts about the religion of the Muslims. Although the texts in this collection all claimed to be based on genuine source material, thereby reflecting the shifting attitude towards the study of Islam, the inclusion of works such as Humphrey Prideaux's Life of Mahomet shows that this new canon of texts was still unable to distance itself from the old polemical tradition. It therefore failed to carry out Reland's wishes and instructions successfully.

Outside the English-speaking world it might actually have been Reland's call to use authentic information about Islam in the fight against it that accounted for its great influence and its many editions and translations. The second, revised edition of Reland's work, which was published in 1717, was, as we saw, largely an expansion of the original work. In addition to the original sources

68 Mention is often made of an additional Spanish translation of the work, e.g. by Van der Aa, Israel, and Hamilton, but I have been unable to trace it.

69 Four Treatises Concerning the Doctrine, Discipline and Worship of the Mahometans. See Pailin, Attitudes to Other Religions, p. 82. 
Reland also made use of contemporary travel literature about the Ottoman Empire and he further supported his exposition with visual material. ${ }^{70}$ Four informative copper plates are added to the text. They contain a diagram of the genealogy of Muhammad, an illustration of the various postures of Muslim prayer, a contemporary view of the Hagia Sophia in Constantinople, and a view of the Holy Mosque, including the Ka'aba, in Mecca. Reland's search for authentic information is even reflected in these images. The view of Mecca was a copy of an illustration sent to him by the Swedish Orientalist Michael Eneman (1676-1714). Reland notes, however, that he had changed the dimensions in order better to reflect the proportions of, and distances between, the buildings from this particular perspective. In doing so he had relied on descriptions in Arabic texts. ${ }^{71}$

At the same time the second edition of De religione Mohammedica contained a more curious addition that seems to violate, rather than support, the author's mission. This is a frontispiece depicting a 'Turkish scene', which is characterised by a certain degree of both decadence and aggression [Fig. 2.1]. The illustration depicts what is probably the Turkish sultan standing on a stage surrounded by an Ottoman crowd. At the back of the stage a male figure stands holding an open book and pointing upwards-most likely representing an Islamic scholar reading from the Qurān. ${ }^{72}$ At the foot of the stage are two decapitated heads of what appear, judging by the lack of headgear, to be executed non-Muslims, thus illustrating Islamic aggression against the nonIslamic world. ${ }^{73}$ The fact that such an illustration was added to the work suggests a slight shift of emphasis in the way in which this publication targeted its audience.

It is probably no coincidence that the second edition of Reland's work should have been published at a time when the tensions between Christian Europe and the Ottoman Empire had increased. Two years earlier, in 1715, the Peace of Karlowitz had been interrupted, and the Habsburgs and Ottomans

70 See Saviello, Imaginationen, p. 16 off.

71 Ibid., p. 162, including n. 13 o.

72 Ibid., p. 165 n. 138.

73 Although beheadings were not unknown in European countries, the beheading of Europeans in the Ottoman Empire was often used to instill fear into the public. In travel accounts such as those of Salomon Schweigger, scenes describing processions in which the heads of decapitated Christians are carried around on stakes are clearly meant to scare the reader and to warn him against the Ottoman/Islamic aggression. As Linda Colley writes, '(...) Western powers were more ready to condemn aggression of the part of Muslim forces, than acknowledge the parallels existing between it and their own actions', Colley, Captives: Britain, Empire, and the World, 1600-1850, p. 45. 
had once again taken up arms. At the same time the relationship between the Ottoman Empire and the Dutch Republic had cooled significantly when France was allowed to take over the Republic's role as the primary partner in the cloth trade. ${ }^{74}$ In this context the centre of gravity of Reland's work might have deliberately shifted from the authentic study and representation of Islam to the fight against the Islamic world on the basis of such new information.

This shift of focus is even more discernible in the Dutch edition of De religione Mohammedica, which was published in 1718, a few months after Reland's death, under the title Verhandeling van de godsdienst der Mahometaanen. In addition to a Dutch translation made by an anonymous author, the work contained three extra documents which were added by the publisher Willem Broedelet: a Dutch translation of Reland's own 'treatise of the martial law of the Muhammedans in times of war against the Christians' (De Jure Militari Mohammedanorum), and two Dutch translations of peace treatises between the Ottoman and Habsburg empires-one composed by the Sultan and one by the Holy Roman Emperor. In a supplementary preface the publisher writes that the addition of these texts seemed 'appropriate' to him, 'at a time when the war of the Ottoman Porte against the Christian powers is in full swing.' ${ }^{75}$ Willem Broedelet thus clearly places the emphasis on Reland's call to fight and refute Islam, rather than on his call for a more scholarly approach to the religion - despite the fact that Reland himself had identified this second point as his main aim.

We can only imagine that Reland would not have been entirely happy with - or have even approved of - this shift of focus. The frontispiece that was added to the 1717 Latin edition and the Dutch translation of De religione Mohammedica is particularly odd since, even if beheadings were not uncommon in the Ottoman Empire, Reland's De Jure Militari Mohammedanorum insists rather on the 'humane' treatment of enemies and prisoners of war. More generally, it presents and explains the multitude of Islamic laws which lay down in great detail all those things that are permitted and prohibited in wartime, including any possible exception. The image, however, suggests the opposite. Especially when observed by someone without any further knowledge, it seems to illustrate aggressive and arbitrary rule by a decadent despot

74 Wheatcroft, De vijand voor de poort, pp. 292-293.

75 '(...) dat wy by het Tractaat van De Godsdienst der Mahometanen, gevoegt hebben zyn Ed. Verhandeling van derzelver Krygsregt, dat (...) geen ongepaste stoffe voor deze tyd scheen, terwyle den oorlog van de Ottomanische Porte tegen de Christen Mogentheden noch in volle vlam staat (...)'. Reland, Verhandeling, p. 1. 
following the Qurānic law. In a work that insists on rationality and order, an illustration that appeals to emotions and fear seems out of place. ${ }^{76}$ Besides, it is inconsistent with Reland's attempt to form an image of Islam and Islamic law purely on the basis of its own written sources. Rather than a deliberate choice by Reland it must therefore have been a decision by the publisher who was trying to sell his work to the broader public by appealing to a general fear of the Turk at the time of the recently resumed war-a situation he also emphasized in his preface to the Dutch edition.

A similar contextualization of Reland's De religione Mohammedica in the Habsburg-Ottoman War can be found in an earlier German translation which had followed the English one and was published in 1716 in Hannover under the title Zwey Bücher von der Türkischen oder Mohammedische Religion. A second edition was published a year later, in 1717. As the title indicates, the work contains a direct German translation of the two books of Reland's De religione Mohammedica. These were supplemented with a 'curious treatise of the Islamic martial law', which was a German translation of the same treatise by Reland added to the Dutch translation, even though the latter was not published until a year later. As the publisher states, this treatise would demonstrate the dangers of an impending 'Türcken-Krieg' to both officers and amateurs. ${ }^{77}$ Another remarkable addition to the German edition of Reland's De religione Mohammedica is a portrait of Muhammad on the frontispiece-a clear violation of the Islamic prohibition to depict the Prophet and possibly even a deliberate provocation of Muslims. Like its Dutch equivalent, the German translation also seems to have emphasised the fight against the Islamic world rather than the objective study of Islam.

So most editions of Reland's work hardly seem to have been aimed at a scholarly audience, nor did they necessarily intend to advocate the objective study of Islam. Rather, they presented Reland's text as an authentic reflection of the religion of Islam which could be used in the struggle against the Islamic world. Nevertheless, these publications did present their vernacular audience with Reland's authentic presentation of Islam and with his outspoken refutation of the old and tenacious misconceptions that had also penetrated the popular image of the religion. These translations could thus undoubtedly have contributed to the improvement or adjustment of this popular image of Islam,

76 In his De Jure Militari Mohammedanorum, Reland again stresses the importance of presenting the Islamic laws of wartime on the basis of authentic texts ('echte stukken'), as they have been defined by Muslims themselves ('zoo als zy het zelve bepaalt hebben'). Reland, Verhandeling, p. 199.

77 '(...) allen Liebhabern, und sonderlich den Officirern sehr nützlich zu lesen', Zwey Bücher, title page. 
despite - or maybe thanks to - their polemical undertone, demonstrating the amplitude of Reland's call for objectivity in the study and representation of Islam even outside the academic field.

\section{Bibliography}

\section{Sources}

Arrivabene, A., L'Alcorano di Macometto, nelqual si contie ne la dottrina, la vita, i costumi, et le leggi sue, Venice, 1547.

De natuurlyke wysgeer, of het Leven van Hai ebn Jokdan, Rotterdam, Pieter Van der Veer, 1701.

Descartes, R., Discourse on the Method and the Meditations, translated by J. Veitch, New York, Cosimo, 2008.

Four Treatises Concerning the Doctrine, Discipline and Worship of the Mahometans, London, J. Darby, 1712.

Oomius, S., Het geopende en wederleyde Muhammedisdom, Amsterdam, W. van Beaumont, 1664.

Picart, B. and J.-F. Bernard, Cérémonies et coutumes religieuses de tous les peuples du monde representées par des figures dessinées de la main de Bernard Picard: avec une explication historique, \& quelques dissertations curieuses, 7 vols, Amsterdam, J.F. Bernard, 1723-1737, completed by Supplements, 2 vols, Amsterdam, J.F. Bernard, 1743 .

Reland, A., De religione Mohammedica libri duo: quorum prior exhibet Compendium Theologiae Mohammedicae, ex Codice Manuscripto Arabice editum, Latine versum, et Notis illustratum. Posterio examinat nonnulla, quae falso Mohammedanis tribuuntur, Utrecht, Willem Broedelet, 1705.

Reland, A., De religione Mohammedica libri duo. Editio altera auctior, Utrecht, Willem Broedelet, 1717 .

Reland, A., La religion des Mahométans: Exposée par leurs propres docteurs avec des éclaircissemens sur les opinions qu'on leur a faussement attribuées, trans. David Durand, Den Haag, 1721.

Reland, A., Palestinae ex monumentis veteris illustrata, Utrecht, Willem Broedelet, 1714. Reland, A., Palestina opgeheldert, ofte de gelegentheyd van het Joodsche land, Utrecht, Willem Broedelet, 1719.

Reland, A., Verhandeling van de godsdienst der Mahometaanen, als mede van het Krygsregt, Utrecht, Willem Broedelet, 1718.

Reland, A., Zwey Bücher von Türckischen oder Mohammedischen Religion, Hannover, 1716 . 
Sale, G., The Koran, Commonly Called the Alcoran of Mohammed, Translated into English Immediately from the Original Arabic; With Explanatory Notes, Taken from the Most Approved Commentators. To which is Prefixed a Preliminary Discourse, London, C. Ackers, 1733 .

Schweigger, S., Ein newe Reyssbeschreibung auss Teutschland nach Constantinopel und Jerusalem. Nürnberg, 1608 .

\section{Studies}

Aa, A.J. van der, 'Reeland (Adrianus of Hadrianus)', Biografisch woordenboek der Nederlanden, vol. 16, Haarlem, J.J. van Brederode, 1874, http://resources.huygens .knaw.nl/retroboeken/vdaa/\#source=aa_oo1biog19_o1.xml\&page $=15^{2} \&$ accessor =accessor_index (accessed 22 July 2019).

Amersfoort, J. van, and W.J. van Asselt, Liever Turks dan Paaps? De visies van Johannes Coccejus, Gisbertus Voetius en Adrianus Relandus op de islam. Zoetermeer, Uitgeverij Boekencentrum, 1997.

Bevilacqua, A., 'The Qur'an translations of Marracci and Sale', Journal of the Warburg and Courtauld Institutes, vol. 76, 2013, pp. 93-130.

Bevilacqua, A., The Republic of Arabic Letters. Islam and the European Enlightenment, Cambridge MA, The Belknap Press of Harvard University, 2018.

Bobzin, H., Der Koran im Zeitalter der Reformation: Studien zut Frühgeschichte der Arabistik und Islamkunde in Europa, Stuttgart, Franz Steiner Verlag, 1995.

Bohnstedt, J.W., 'The Infidel Scourge of God: The Turkish Menace as Seen by German Pamphleteers of the Reformation Era', Transactions of the American Philosophical Society, vol. 58, no. 9, 1968, pp. 1-58.

Bouyges, M., Essai de Chronologie des CEvres de al-Ghazali, Beyrouth, Imp. Catholique, 1959 .

Burman, T., Reading the Qur'an in Latin Christendom 1140-1560, Philadelphia, University of Pennsylvania Press, 2007.

Burman, T., 'Tafsīr and Translation: Traditional Arabic Qurān Exegesis and the Latin Qurāns of Robert of Ketton and Mark of Toledo', Speculum, vol. 73, no. 3, 1998, pp. 703-732.

Colley, L., Captives. Britain, Empire, and the World, 1600-1850, London, Pimlico, 2003.

Daniel, N., Islam in the West. The Making of an Image, Edinburgh, Oneworld, 1960.

Dohmen, C., In de schaduw van Sheherazade. Oosterse vertellingen in achttiende-eeuws Nederland, Nijmegen, Vantilt, 2000.

Elmarsafy, Z., The Enlightenment Qur'an. The Politics of Translation and the Construction of Islam, Oxford, 2009.

Geier, A., “Also ist der Turcke auch vnser Schulmeister ..." Zur Rhetorik von Identität und Alterität in Türkenschriften des 16. Jahrhunderts', in W. Neuber et al. (eds), Rhetorik. Ein internationales Jahrbuch, vol. 22, 2003, pp. 19-42. 
Hamilton, A., 'Adrianus Reland (1676-1718). Outstanding Orientalist', in H. Jamin (ed.), Zes keer zestig. 360 jaar universitaire geschiedenis in zes biografiën, Utrecht, Universiteit Utrecht, 1996, pp. 22-31.

Hamilton, A., 'After Marracci: The Reception of Ludovico Marracci's Edition of The Qur'an in Northern Europe from the Late Seventeenth tot he Early Nineteenth Centuries', Journal of Qur'anic Studies, vol. 20, no. 3, 2018, pp. 175-192.

Hamilton, A., 'From a “Closet at Utrecht”. Adriaan Reland and Islam', Nederlands Archief voor Kerkgeschiedenis, vol. 78, no. 2, 1998, pp. 243-250.

Hamilton, A., 'Western Attitudes to Islam in the Enlightenment', Middle Eastern Lectures, vol. 3, 1999, pp. 69-85.

Hunt, L., M.C. Jacob, and W. Mijnhardt, The Book that Changed Europe. Picart \& Bernard's Religious Ceremonies of the World, Cambridge MA, The Belknap Press of Harvard University Press, 2010.

Israel, J., Enlightenment Contested: Philosophy, Modernity, and the Emancipation of Man, 1670-1752, Oxford, Oxford University Press, 2006.

Leeuwen, R. van, and A. Vrolijk, 'Oriëntalistiek in de Lage Landen. De "verlichte” oriëntalist Adriaan Reland', ZemZem, vol. 5, no. 1, 2009, pp. 54-67.

Loop, J., 'Islam and the European Enlightenment', in D. Thomas (ed.), Christian-Muslim Relations 1500-1900, Leiden and Boston, Brill, https://referenceworks.brillonline .com/entries/christian-muslim-relations-ii/*-COM_32830 (accessed 23 January 202O).

Matar, N., 'Humphrey Prideaux', in D. Thomas (ed.), Christian-Muslim Relations 1500190o, Leiden and Boston, Brill, https://referenceworks.brillonline.com/entries/ christian-muslim-relations-ii/humphrey-prideaux-COM_29577?s.num=o\&s.f.s2 _parent=s.f.book.christian-muslim-relations-ii\&s.q=prideaux (accessed 23 January 2020).

Matar, N., 'The True Nature of Imposture Fully Display'd in the Life of Mahomet', Christian-Muslim Relations 1500-1900, Leiden and Boston, Brill, https://reference works.brillonline.com/entries/christian-muslim-relations-ii/the-true-nature-of -imposture-fully-displayd-in-the-life-of-mahomet-COM_29578 (accessed 22 January 2020).

Nat, J., De studie van de Oostersche talen in Nederland in de 18e en 19e eeuw, Purmerend, J. Muusses, 1929 .

Pailin, D., Attitudes to Other Religions. Comparative Religion in Seventeenth- and Eighteenth-Century Britain, Manchester, Manchester University Press, 1984.

Roling, B., 'Humphrey Prideaux, Eric Fahlenius, Adrian Reland, Jacob Ehrharth und die Ehre des Propheten: Koranpolemik im Barock', in D. Klein and B. Platow (eds), Wahrnehmung des Islam zwischen Reformation und Aufklärung, Berlin, Wilhelm Fink, 2008, pp. 62-69. 
Saviello, A., Imaginationen des Islam: Bildliche Darstellungen des Propheten Mohammed im westeuropäischen Buchdruck bis ins 19. Jahrhundert, Berlin, De Gruyter, 2015.

Tommasino, P.M., The Venetian Qur'an: A Renaissance Companion to Islam, Philadelphia, University of Pennsylvania Press, 2018.

Wheatcroft, A., De vijand voor de poort: De Habsburgers, het Ottomaanse Rijk en de slag om Europa, translated by J. Braks, Amsterdam, Atlas, 2010.

Wiegers, G.A., 'De Nederlanden en islam in de zeventiende eeuw: wisselwerking tussen cultuurcontact en beeldvorming?', in W.A. Shadid and P.S. van Koningsveld (eds), Religie, cultuur en minderheden. Historische en maatschappelijke aspecten van beeldvorming, Tilburg, Tilburg University Press, 1999, pp. 141-153.

Wiegers, G.A., 'Review of Translations of the Qur'ān in Medieval and Early Modern Iberia', Medieval Encounters, vol. 32, 2015, pp. 121-130. 